\title{
Islam and the Discovery of Freedom
}

By Rose Wilder Lane, with an introduction and commentary by Imad-adDean Ahmad. Amana Publications and Minaret of Freedom Institute, 1997, 86 pp.

This very stimulating and perceptive work was born out of the author's solid conviction that freedom is the ideal that all societies should strive for and that the history of humanity has been one of constant struggle against oppressive forces of authority in order to realize this utopia. The original edition of her work, The Discovery of Freedom: Man's Struggle Against Authority, unfortunately lacked academic credibility due to several factual errors it contained, and was withdrawn from circulation after its publication by the author herself, and would have been relegated to the obscurity of history were it not for the work of Dr. Imad-ad-Dean Ahmad. He chose to concentrate on the section of her work relating to Islam and published it separately from the original version under this new title, Islam and the Discovery of Freedom. By providing detailed annotations and a running commentary throughout, as well as rectifying most of the historical errors, he has been able to redeem the force and quality of the author's original argument.

Although more famously known for her mother's best selling book, Little House on the Prairie, Rose Wilder Lane (1886-1968) was a journalist dedicated to the cause of freedom as well as a best selling author and biographer in her own right. She acquired her knowledge of Islam through her work for the Red Cross just after the First World War when she documented their activities in Russia, the Balkans and the Middle East.

To understand the important place Mrs. Lane has given to Islam one has to understand the central thesis of her original work. She maintains that mankind has made three notable attempts to free itself from the shackles of oppressive power and authority. The first attempt was orchestrated by the Prophet Abraham, the second by the Prophet Muhammad and the third, though less radical, resulted from the American Revolution. Her study highlights the dangers of unbalanced distribution of power, for she argues that vesting total control and authority in a single leader or small group of people is highly dangerous as the word and opinion of that authority can very easily become Law, suppressing, and even persecuting, all those with different views. Furthermore, she asserts that this state of affairs is nowhere more apparent nor more dangerous than in the societies whose leader(s) claim to speak for or act in accordance with "the will of God."

The example of Abraham is used to reflect a society where superstition and the capricious will of its gods dominated all areas of life. It is a type of control 
that relies upon and uses the anxieties and frailty of man, especially when faced with sudden unexplained disasters and waves of destruction. In such a society, the people chose to submit to the will of their gods and their spokespersons (the priests) in order to ensure that they would be taken care of and protected. But this submission is a loss of freedom because it is rooted in fear and is consequently a type of authoritarianism that both prophets Abraham and Muhammad condemned. The Prophet Muhammad, however, went one step further in that he successfully challenged not only the religious domination of idols but also the political and economic domination of the corrupt Makkan leadership. Indeed Mrs. Lane argues that corruption, deceit, and immorality are the natural side-effects of authoritarian systems, because bribery, theft or other crimes can flourish easily in a system where there is no power check and the person(s) in authority can exercise and impose their unfettered will. Finally, she states that the third great manifestation of society's desire to realize the freedom of its citizens appeared in the spirit of the American Revolution, although she acknowledges that American libertarianism could not have been built without the foundations that had been laid by the two former attempts.

The greater part of her book is devoted to a discourse on the achievements of the Muslim world at the time of the Crusades. The crusaders' invasion (although defilement would be a more apt word judging by the passionate and angry tone in which this part of the book is written) is examined in terms of the comparatively advanced nature of the peoples they were conquering. Mrs. Lane compares descriptions of the barbarity and uncouth manner of the crusaders and their home kingdoms to their almost rapturous admiration for the jeweled cities they entered. She quotes: "Imagine the crusader ... wearing harsh leather, and used to gnawing meat heartily from the bone, tossing the bone to the dogs, and pouring down his throat a quart of ale," which is in stark contrast to, "The fabrics seemed magical; chiffons that clung like cobwebs to fingers ...; some vessels were transparent like jewels, seize one, it crushed to pieces ... it was glass." Another of Mrs. Lane's brilliant descriptions relate to the Muslim conquest of Spain.

The central point of her entire thesis is the realization that there is only One True God - by whatever name one chooses to address Him - and that He has granted mankind the freedom to choose between good and evil and to learn from his experiences in order to grow towards Him and be rewarded by a place in paradise in the hereafter. However, in her understanding of Islam and of the politics of power in general, Mrs. Lane does not seem to fully appreciate the relationship between accountability and decision-making. Indeed, society cannot function without some sort of a hierarchical structure, which is normally manifested in the leadership of one person, and in the case of Islam it is the 
Caliph. This leadership serves to unify all the members of a society and provides a practical structure to what would otherwise be total confusion, and it does not have to be in the form of absolute power if certain controls are introduced. In Islam these controls are formed by accountability and collective decision-making which are rooted in the Qur'an and the Sunnah. The leader is granted power through a democratic process; he is accountable to God for all his actions and has to rule in accordance with the principles laid down by the Qur'an and the Sunnah. He also has to discuss matters and decisions with a body of trusted advisors and Islamic scholars. Without understanding the infinite number of ways in which the Qur'an and the Sunnah can ensure this accountability, Lane could not possibly understand the full depth of Islam's political structure. According to Islam each society must have laws and supreme authorities to govern it. Each person in power is answerable to God and not to his/her own notions of what is right. And if a leader puts forward an idea that is not in keeping with the will of God (as revealed in the Qur'an and the Sunnah) he/she will immediately be challenged by the Muslims for it is their duty to refuse to accept or obey a ruling that is contrary to God's will. This is why the role of the scholars is so important as they must study the texts with care and through the practice of ijtihad give interpretations where necessary.

Islam and the Discovery of Freedom offers wonderful insight into some of the great achievements of Islam - a subject barely touched on by the education syllabi of the West. The author's rhetoric and imaginative style go a long way to make up for her errors, although some of these are serious, such as her lack of understanding that a sophisticated system of law and organization exist in Islam. Yet the importance and real significance of her work lies in the ideas she presents and her open-minded approach to Islam - at a time when views about Islam and the Muslim world were mainly governed by prejudice, and when most literary works available were consequently a reflection of the orientalist and biased views of their authors.

Ruqaiyyah Waris Maqsood Writer and Teacher UK 